Marie-Eve Bouchard*

\title{
Redefining Forro as a marker of identity: Language contact as a driving force for language maintenance among Santomeans in Portugal
}

https://doi.org/10.1515/multi-2020-0082

\begin{abstract}
In São Tomé and Príncipe, the language shift toward Portuguese is resulting in the endangerment of the native creoles of the island. These languages have been considered of low value in Santomean society since the mid-twentieth century. But when Santomeans are members of a diaspora, their perceptions of these languages, especially Forro, change in terms of value and identity-marking. It is possible to observe such changes among the Santomeans who learn Forro when they are abroad, who use it as an in-group code, and start to value it more. In this article, I address the role of language contact in the maintenance and expansion of Forro. I investigate the mechanisms of language maintenance by focusing on the shifts in community members' attitudes and beliefs regarding their languages, as a result of contact. The changing attitudes and beliefs have led to a redefinition of the role of Forro in the speech community. This qualitative study is based on semistructured interviews conducted on São Tomé Island and in Portugal. Findings suggest that the change in value attributed to Forro by Santomeans as a result of contact contribute to the valorization of the language.
\end{abstract}

Keywords: language attitudes, diaspora, in-group code, language contact, language maintenance, São Tomé and Príncipe

\section{Introduction}

Language practices in most of Africa today reflect colonial times, when European colonial languages were emblems of economic, political, and social power (Mazrui and Mazrui 1998; Mufwene and Vigouroux 2008). This is the case in São Tomé and Príncipe, where Portuguese was adopted as the only official language of the

\footnotetext{
*Corresponding author: Marie-Eve Bouchard, Department of French, Hispanic and Italian Studies, The University of British Columbia, \#715-1873 East Mall, Buchanan Tower, Vancouver, British Columbia, V6T 1Z4, Canada, E-mail: mebouchard@nyu.edu. https://orcid.org/0000-0002-05250821
}

Ә Open Access. @ 2020 Marie-Eve Bouchard, published by De Gruyter. (ㄷ)BY under the Creative Commons Attribution 4.0 International License. 
country in 1975, after its independence from Portugal. Today, Portuguese is spoken by $98.4 \%$ of the Santomean population (INE 2012). It is the language of the government, media, and school, the first language of most Santomeans, and the language of everyday life. The ongoing language shift from the native creoles of the islands (Forro, Angolar and Lung'ie) to Portuguese is resulting in the decreasing use of these creoles. Language shift is the process whereby a speech community (usually bilingual or multilingual) in a contact situation gradually stops using one language in favor of another language. However, little attention has been given to this language shift and the endangerment of the three native creoles of São Tomé and Príncipe. These creoles are at different stages on the ethnolinguistic vitality scale. According to Eberhard et al. (2020) and based on the Expended Graded Intergenerational Disruption Scale (Lewis and Simons 2010), Forro is shifting, Angolar is vigourous, and Lung'ie is nearly extinct.

Forro, Angolar, and Lung'ie are contact languages that developed during colonial times, most likely in the sixteenth century (Hagemeijer 2009). Garrett (2006: 48) defines contact languages as languages that have emerged from situations of social contact among speakers of two or more previously existing languages. These include pidgins, creoles, and mixed languages. According to Lee (2018, 2020), 95.8\% of contact languages are at some level of endangerment or are already extinct, a number that is almost twice that of the world's languages (49.5\%). The endangerment of contact languages has received less attention in the scholarly literature than their emergence (e.g., Kouwenberg and Singler 2008; Siegel 2008). Nevertheless, in the last decade, this topic has been given increased attention (e.g., Garrett 2012; Lee 2017, 2018, 2020; Mufwene 2017; O’Shannessy 2012). This paper fills a gap by taking an interest in the dynamics that sustain the vitality of contact languages.

Contact between Portuguese settlers and their slaves on São Tomé and Príncipe Islands led to the emergence of Forro, Angolar and Lung'ie after Portugal took possession of the islands (around 1470). But a second contact with these Portuguese settlers and contract laborers coming from Africa in the 19th and 20th centuries contributed to a language shift from these creole languages to Portuguese. Thus, a first contact with Portuguese favored the creation of these languages, but a second contact, four centuries later, prompted their endangerment. Against this backdrop, I now ask the following question: Can another contact with Portuguese play a role in the maintenance and expansion of these creole languages, more specifically of Forro?

This article focuses on Forro, which is the most vastly spoken creole on São Tomé Island. It is traditionally the language associated with Santomeans who identify as Forros. "Forros" was the name given to the enslaved Africans who were freed by their masters during colonial times. These Forros participated actively 
in the formation of the creole society (Seibert 2006). They were the filhos da terra, 'children of the land', the descendants of the first Portuguese colonizers and their African slaves. The Forros climbed up the social scale of the island during the 17th and 18th centuries, when the Portuguese lost interest in São Tomé and Príncipe. During this period, the Forros became owners of land and slaves, and they became the most powerful social group of São Tomé Island (Lorenzino 1998). The other sociocultural groups of the islands are the Angolares, Principenses, Tongas, and Cabo Verdeans. The Angolares are descendants of marooned enslaved Africans who escaped from the plantations and formed their own community at the beginning of the colonization of São Tomé Island by the Portuguese. They lived on the southern side of the island, and spoke their own creole, called Angolar. The Principenses, the minu ie, 'child (of the) island', are the natives of Principe Island. Settlement on Principe Island started in 1500 (Maurer 2009), probably with Portuguese colonists and their African slaves coming from São Tomé Island. The native creole of Príncipe is Lung'ie, which means "language of the island" (Maurer 2009: 3). The Tongas are mixed-race Santomeans, descendants of foreign workers coming mainly from Angola, Cabo Verde, and Mozambique, who came to São Tomé and Príncipe during the twentieth century as contract laborers. Some Cabo Verdeans were part of the formative populations for the Tongas, but other Cabo Verdeans maintained a separate identity that persists to this day.

In this article, I address sociolinguistic dynamics of language practice among Santomeans who have lived in Portugal and the extent to which these dynamics can shed light on language maintenance. I anchor my discussion in the history of São Tomé Island, ${ }^{1}$ the consequences of language contact, and the values attributed to the different languages in Santomean society. I investigate the mechanisms of language maintenance by focusing on one main factor: the changing attitudes and beliefs of the community's members regarding their languages that have resulted from contact. Positive attitudes are one of the social factors that drive language maintenance. This factor is considered central in the maintenance or loss of a language (Austin and Sallabank 2014; Belew and Simpson 2018; Sallabank 2013). To investigate the dynamics that sustain the vitality of Forro, I explore how the perceptions Santomeans have about this language have changed in terms of value and identity marking. This change is manifested through Santomeans who learn Forro when they are abroad and start to value it more. It is also observable when Santomeans use Forro as an in-group code.

In Section 1 of this article, I discuss language vitality on São Tomé Island and review the existing literature on this topic. Section 2 presents the theoretical

1 I mostly leave Príncipe aside, as it has a different history than São Tomé, and the language shift on this island is basically completed. 
framework that guides this research; it draws on the concepts of language contact and linguistic market. In Section 3, I summarize my field research and data collection. In Section 4, I present and analyze data focusing on the experience of Santomeans who have lived and learned Forro outside São Tomé Island. The analysis of interview excerpts, combined with participant observation in the local community and in Portugal, reveals how contact between Santomeans and other Portuguese speakers led to a redefinition of Forro as a marker of Santomean identity and an ingroup code. In the closing section, I argue that the change of value attributed to Forro by Santomeans themselves contributes to the valorization of the language. However, if no concrete preservation efforts are undertaken, this valorization will most likely not be sufficient to increase the use of Forro on São Tomé Island and in the diaspora and will not be enough to keep this creole language alive.

\section{The vitality of languages in São Tomé and Príncipe}

Africa is home to nearly one-third of the world's languages (an estimated number of 2,140 [Eberhard et al. 2020]), and 28.3\% of these languages are considered to be endangered (Belew and Simpson 2018). In many cases, the population is shifting from their native language to a majority language (i.e., the former colonial language, or the language of a major powerful indigenous language) (Batibo 2009). Although language shift may be associated with language death (which itself represents an erosion of human knowledge, loss of cultural heritage, and failure to acquire full understanding of human cognitive capacities [Harrison 2007]), it is not necessarily negative. It can be interpreted as a process of responding to socioeconomic changes, and the shifting population, or at least part of it, usually benefits from the shift (Perez 2019). Losing a language does not necessarily entail losing ethnic and cultural identity, as there are other markers to fulfill this role (Mufwene 2017).

Swadesh (1948) urged fieldworkers to collect and report data that may shed light on the processes of language shift and loss. Since his work, linguistics has made significant progress in understanding the dynamics that sustain language vitality. Language vitality refers to the extent that a language is used as a means of communication within a community in various social contexts. Following Mufwene (2017), I choose the term vitality to refer to language endangerment, loss, and death, but also language maintenance and expansion. Vitality is assessed using schemas that operate on different criteria, including intergenerational transmission, number of speakers, domains of use, and availability of material for language education. The combination of scores on each criterion results in a vitality rating for the language as a whole. The language is then 
placed on a vitality scale that ranges from safe to critically endangered. The most well-known vitality schemas are the Graded Intergenerational Disruption Scale (Fishman 1991), the UNESCO's nine factors (UNESCO 2003), the Extended Graded Intergenerational Disruption Scale (Lewis and Simons 2010), and the Language Endangerment Index (Lee and Van Way 2016). However, Lüpke and Storch (2013) and Lüpke (2015) argue for the development of Africa-specific criteria to assess language vitality. In fact, the criteria mentioned above do not necessarily apply to African settings. For instance, criteria such as number of speakers and urbanization have no straightforward negative impact on the vitality of a language in the African context (Lüpke 2015). Rather, they suggest that the criteria for assessing the vitality of African languages include (1) the existence of communities of practice and social networks for language socialization, (2) a home base for these communities of practice and social networks, (3) socioeconomic and political stability, (4) community members' attitudes toward their own languages, and (5) the recognition of these languages as fully-fledged languages.

When they became independent, African countries had to choose between adopting an exoglossic policy that promoted the ex-colonial language as the official language of the country, or an endoglossic policy that promoted a native language as the official language (Batibo 2009). Most countries opted, as São Tomé and Príncipe did, for the first option. Since its independence, São Tomé and Príncipe has been moving toward monolingualism and its population is witnessing the loss of its creole languages. During colonial times, urban Santomeans and education officials denigrated all creoles of the islands as the languages of the poor uneducated rural people and did not allow their children to speak it. They were afraid that creole would hinder the acquisition of Portuguese and limit their social mobility. This contributed to a rapid language shift, mainly in the capital and its surrounding areas, from Forro to a Santomean variety of Portuguese (Bouchard 2019a; Hagemeijer 2018). According to the last census, Forro is still the most widely spoken creole in the country, with $36.2 \%$ of the population reporting speaking it. As for the other creole languages, $6.6 \%$ of the population reported speaking Angolar, 1.0\% reported speaking Lung'ie, and 8.5\% of the population also reported speaking Cabo Verdean Creole (Table 1).

Table 1: Percentage of speakers per language (1981-2012).

\begin{tabular}{rrrrrrr}
\hline & Total population & Portuguese & Forro & Lung'ie & Angolar & Cabo Verdean \\
\hline 1981 & 96,661 & $62.6 \%$ & $56.3 \%$ & $1.6 \%$ & - & - \\
1991 & 117,504 & $80.8 \%$ & $59.5 \%$ & $1.3 \%$ & - & - \\
2001 & 137,599 & $99.3 \%$ & $72.4 \%$ & $2.4 \%$ & - & - \\
2012 & 173,015 & $98.4 \%$ & $36.2 \%$ & $1.0 \%$ & $6.6 \%$ & $8.5 \%$ \\
\hline
\end{tabular}

Adapted from Gonçalves and Hagemeijer (2015: 91) and INE (2012). 
The shift from Forro to Portuguese is vastly discussed in Bouchard (2019a), in which the author considers language ideologies to be key to understanding this shift. Starting around the middle of the twentieth century, Forros have adopted the language of the colonizers to show that they are distinct from the other groups on São Tomé Island (Angolares, Cabo Verdeans, and Tongas). The choice of speaking Portuguese is a marker of their distinctive and superior social status. Probably in part because Forros were the people in political power in 1975, at the time of independence, Portuguese became the official language of the country and also a symbol of santomensidade, 'Santomean-ness.' But of course, ideologies alone do not explain the language shift; a combination of factors played a role in this shift, including urbanization, schooling in Portuguese, and a desire to take part in the international community.

The shift from Angolar to Portuguese on São Tomé Island is not as advanced as it is among Forros. Fewer studies have been conducted on Angolar (cf. Lorenzino 1998; Maurer 1995) and to my knowledge, the variety of Portuguese spoken by the Angolares specifically has not been investigated. But according to Bouchard (Forthcoming a), 92.5\% of the students of João dos Angolares self-report themselves as speakers of Angolar (compared to 37.5\% of students in São Tomé City who self-report as speakers of Forro). This number is surprisingly high. Their proficiency was not evaluated, so it might be the case that these young Angolares, due to being more attached to their language as an identity marker, have a more flexible definition of what speaking Angolar entails. In other words, people who only speak some creole or have a low level of proficiency might have answered that they do speak it. That being said, the level of bilingualism among Angolares is considered to be higher (Bouchard 2019b).

Lung'ie on Príncipe Island is basically extinct. According to Agostinho (2014), the remaining number of speakers of Lung'ie varies between 20 and 1300, depending on the source. Valkhoff (1966: 85) wrote that already in 1958, it was difficult to find native speakers. Today, as I am writing these words, there are still a few (bilingual) native speakers living on Príncipe Island. Maurer (2009) considers that Lung'ie is a moribund language for four principal reasons: the epidemic of sleeping sickness killed many native speakers and then motivated the immigration to Príncipe of workers coming from different linguistic backgrounds, the language has not been transferred to the youngest for a period of three to four generations, the newcomers on the island of Príncipe were not encouraged to learn Lung'ie, and the speakers of Lung'ie do not form a territorially homogeneous community. Consequently, the most commonly spoken language on the island after Portuguese is Cabo Verdean Creole.

However, in recent years, Santomeans have started to value their creoles as part of their national identity. I show in this article that the recognition of Forro as 
an identity marker comes in part from Santomeans who have lived or studied abroad. In fact, many Santomeans have learned Forro abroad and started using it more frequently in their interactions with other Santomeans. To them, Forro is a unifying force, one that they use to set themselves apart from other Portuguese speakers when they are abroad.

On São Tomé Island, there is also a desire to undertake preservation efforts and introduce Forro in the schools. Concretely, these preservation efforts can be observed today on local radio and television, which have programs that promote the maintenance and practice of Forro, and also through the work of musicians and singers (who sing in both Forro and Angolar, depending on their origin) (Bouchard forthcoming $\mathrm{b}$ ). There is also an effort coming from the community of linguists, who have described grammars (e.g., Maurer (1995) on Angolar; Maurer (2009) on Lung'ie), written dictionaries (e.g., Araujo and Hagemeijer (2013) for ForroPortuguese, Maurer (1995) for Angolar-Portuguese, Araújo (2012), and Araújo et al. (in preparation) for Lung'ie-Portuguese), and proposed a unified orthography for the native creoles of both islands, called the Alfabeto Unificado para a Escrita das Línguas Nativas de São Tomé e Príncipe (ALUSTP) 'Unified Alphabet for the Writing of Native Languages of São Tomé and Príncipe’ (Pontífice et al. 2010). The effort of revitalization has been particularly important on Príncipe Island (cf. Agostinho 2014, 2016; Agostinho et al. 2016; Lavres and Lavres 2016; among others). However, many Santomeans place in the hands of the government the responsibility of maintaining Forro and providing the conditions that would allow Santomeans to learn and practice Forro. On could ask: Is there a real desire from the policy makers and educators to implement the learning of Forro in schools? Does the government want to promote bilingual education (such as exists in Haiti and Jamaica, for instance), with both Forro and Portuguese? Many Santomeans have told me that this is under discussion, already in the government's hands, but I have not seen or heard of any concrete plans to introduce the use of creoles at a national level.

\section{Framework: Language contact, linguistic market and commodification of language}

This research draws on previous work on language endangerment as a result of language contact, Bourdieu's (1991) linguistic market, and the commodification of language. First, the literature on language endangerment in contact situations (cf. Garrett 2006, 2012; Lee 2020; Thomason 2018) and the consequences of contact (cf. Makihara and Schieffelin 2007; Sankoff 2001) is vast, and I cannot do justice to this extensive body of work in this article. On the one hand, causes of language 
endangerment in contact situations have been widely studied, and these include conquest, colonization, economic pressures, language politics, language attitudes, and standardization, among others. On the other hand, the possible outcomes of language contact include creole formation, code-switching, borrowing, language change, multilingualism, language endangerment and death, also among many others. Language contact has played an eminent role in the creation of the three creoles autochthonous to São Tomé and Príncipe during the sixteenth century, but also in the language shift from these creoles to Portuguese and their endangerment starting during the twentieth century. This article focuses on the endangerment of one of them, Forro, and the consequences of contact between Santomeans who speak Portuguese as their first language and other Portuguese and creole speakers. To my knowledge, no studies exist on the valorization of Forro as a result of contact.

Second, power inequalities exist on São Tomé Island because of language use, and Bourdieu's (1991) notion of linguistic market provides a useful framework for understanding Santomeans' evaluations and uses of Portuguese and creole(s). For Bourdieu, not all languages are socially equal, and the unequal values that languages and language varieties acquire in a particular society translate into economic value, which he calls linguistic capital. The linguistic market is built on economic relation, within which certain languages (or features, registers, varieties) have a higher currency than others. In this view, language reflects social differences and inequalities (Bourdieu 1991; Gal 1989; Irvine 1989), but is also part of what creates social order in society (Heller 2010).

Third, the work on the commodification of language (Del Percio et al. 2017; Heller 2003, 2010) is also relevant to this article. For Appadurai (1986: 13), commodities are "things in a certain situation, a situation that can characterize many different kinds of things, at different points in their social lives.” In this view, any language, variety, or linguistic feature can be perceived as a commodity, depending on the situation (or on the linguistic market, to use Bourdieu's term). According to Heller (2010), languages can be commodified in two ways: as a technical skill and as a sign of authenticity. In the Santomean linguistic market, Portuguese is the most prestigious language; it is valuable for social promotion, on the job market, and it opens doors to the world outside São Tomé and Príncipe, especially to the Portuguese-speaking world (which expands from Africa to Europe, South America and Asia). Creoles are associated with Santomean history, culture, and the different groups that form the society.

In this article, I situate the endangerment of Forro within this broader framework. I argue that through language contact, Forro gains value on the Santomean linguistic market and is being redefined as a marker of what is authentically Santomean. 


\section{Fieldwork and data collection}

This qualitative study is based on 15 months (between 2015 and 2017) of ethnographic fieldwork on São Tomé Island, and one month in Portugal (in 2019). Data were collected by three major means: tape-recorded semi-structured interviews, observation, and fieldnotes. I conducted a total of 118 interviews in São Tomé and Príncipe, with participants from different communities (rural and urban settings), social classes, sociocultural affiliation, age, and background, and 40 interviews in three different cities of Portugal (the capital, Lisbon, and two cities of Central Portugal). Participants for this study were found through the friend-of-a-friend technique (Milroy 1980), which worked particularly well because the country is small, and most Santomeans know many people through their large and extended families and social networks. Topics of conversation during the interviews varied greatly from one participant to another, depending on their realities and interests. This means not all participants discussed the vitality of Forro or shared information relevant to this article. The discussions followed the trains of thoughts of the interviewees. Ethnographic observations were made in the public (school, artistic events, political speeches, national celebrations) and private spheres (family, groups of friends, gatherings). These allowed me to understand community and local practices, group dynamics, social order, ideologies, and subtle information that might be more difficult to obtain in interviews. Fieldnotes were taken nonconsistently (more regularly at the beginning, less frequently towards the end) throughout my stays on São Tomé Island and in Portugal.

Assessment of competency in Forro, based on the participants' self-evaluation, was included in the interviews. Participants were asked if they speak Forro (or other creole languages), how they learned the language(s), with whom and how often they speak creole nowadays, and how comfortable they feel speaking it.

The qualitative analysis of the interviews is based on discourse analysis, which was conducted on the participants' narratives. The parts of the interviews dealing with the use of creole were transcribed. Excerpts are used to support my observations and discuss the themes that emerged as most relevant in the data. The excerpts I selected come from five Santomeans who brought up the use of Forro as an ingroup language or discussed the values attributed to Forro. These five participants grew up in São Tomé City, they speak Portuguese as a first language, and from a Santomean perspective, they are economically comfortable - or at least, comfortable enough to move abroad to pursue their studies. Alberto, Bibiana and Sandra were interviewed in São Tomé City in 2015-2016; they are among the Santomeans who made me aware of this change of linguistic practice when abroad. Flor and 
Clara, whom I first met in 2015 in São Tomé City, were interviewed in Portugal in 2019. Pseudonyms are used in all cases to maintain anonymity.

\section{Contact and the perceived need for an in-group code}

In this section, I examine the perceived need for an in-group language that emerges among Santomeans when they are abroad, in contact with other speakers of Portuguese and creole, and how this contact may lead to a more expansive use of Forro, its valorization, and a redefinition of its roles.

The lack of value given to the creole languages of São Tomé and Príncipe has certainly contributed to their endangerment. On São Tomé Island, starting probably in the middle of the twentieth century, when the shift from Forro to Portuguese was intensified as Forros were concerned with gaining access to Portuguese, the transmitted belief was that Portuguese was "better" than Forro and all other creoles, and that speaking Forro was not acceptable. Older Santomeans remember that in their youth, Forro was considered to be a lingua de bicho 'animal's language', feio 'ugly', inferior 'inferior', and marginalizado 'marginalized' (Bouchard 2017). These evaluative comments, or stereotypes, to describe Forro circulated among Forros and were normalized through their everyday use. As a result, many Santomeans have not learned Forro. In the following excerpt, Alberto discusses how living in Brazil impacted his use of Forro, and relates the low frequency of use of Forro on São Tomé Island to the pejorative beliefs that many Santomeans have regarding creole languages.

\section{Excerpt 1.}

Antes de sair daqui de São Tome, acho que se falei forro na minha vida foi uma ou duas vezes, mas... [Author: Ah, é?] Sim, mas o tempo que tive fora falei a perder de conta. [...] Acho que aqui na cidade ficou aquela coisa de. quem é minimalmente letrado não fala crioulo forro, fala português, ou seja, o bom... Teve-se aquela fase né, que o bom era falar português, o pessoal ficou muito travado nisso no tempo, e acho que houve... digamos um desprezo pela... pelo forro que até hoje ainda não saiu inteiramente de nos.

'Before moving out of São Tomé, I think I'd only spoken Forro once or twice in my life, but ... [Author: Really?] Yes, but when I was abroad, I spoke it so often I lost count. [...] I think that here in the city, the belief is that ... people who are even minimally literate don't speak Forro, they speak Portuguese, namely, the good ... There was that period, right, when the good thing was to speak Portuguese, people got stuck with that belief back then, and I think there was ... let's say contempt for ... for Forro, a contempt that hasn't totally left us yet.'

(Alberto, 32 years old, interviewed in São Tomé City) 
Alberto establishes a link between literacy and language choice. The belief that existed (and probably still exists) in São Tomé City is that literate Santomeans use Portuguese and illiterate Santomeans use creole. In this sense, language choice reflects socioeconomic class. This belief is still anchored in the mind of many Santomeans ("a contempt that has not totally left us yet"), and is reflected on the vitality of the creoles of São Tomé Island, with the use of Forro (and the other creoles) continuously decreasing. Being considered illiterate can be shameful, and such negative beliefs and attitudes toward a language and its speakers are effective in endangering a language (Thomason 2018). People have notions about the linguistic capital of the available languages in the market; they know whether it is socially better to speak one language or another. For many Santomeans, speaking Portuguese appeared as a way to maintain or gain a privileged status, and to create a distance with creole speakers, who were associated with a lower social status. It is common in the history of colonial and creole societies to see the language of the colonizers maintaining prestige through time. For example, English is the language of prestige in Jamaica (Wassink 1999), French in Haiti (Hebblethwaite 2012), and Dutch in Aruba, Bonaire, and Curaçao (Dijkhoff and Pereira 2010).

Before moving to Brazil, Alberto already had some knowledge of Forro, which he had acquired from his grandmother, but Bibiana did not. Her only contact with Forro was also with her grandmother, but she rarely spoke it with her. Even so, Bibiana said during her interview that when she was in Portugal, Forro was the language she would use when she met with Santomeans.

Excerpt 2.

Eu lembro-me que, regra geral, em São Tomé, dificilmente falava o crioulo forro, até porque na minha casa meus pais não falavam nem... nem a minha mãe, não falavam crioulo, geralmente com minha avó, aah... também em relação a ela era muito, muito pouco. Eu lembro quando cheguei a Portugal, quando via um Santomense, o que saía de facto era o crioulo forro.

'I remember that, generally speaking, in São Tomé, I barely spoke Forro, because at home, my parents didn’t speak it ... my mother either, they didn’t speak creole, usually with my grandmother, aah ... even with her, it was very, very rare. I remember when I arrived in Portugal, when I'd see a Santomean, what would come out of my mouth would be Forro.'

(Bibiana, 54 years old, interviewed in São Tomé City)

In this excerpt, Forro is presented as a natural expression of being Santomean. Bibiana grew up in the 1960s, at a time where it was common, especially around the capital, for parents to forbid children to speak creole. As such, she grew up speaking Portuguese at home and at school. But migrating to Portugal brought out a connection between Santomeans and Forro, between nationality and heritage 
language, as she started to use it more frequently. Many Santomeans who have migrated to Portugal have mentioned this link between Forro and national identity. This certainly indicates that a change in the belief system of Santomeans occurs during and after their migratory experience. Instead of being associated with lower socioeconomic class, or reflecting low prestige, Forro becomes associated with identity. Its use expresses the speaker's belonging to the Santomean community.

Sandra is a descendant of Cabo Verdeans. Even if she does not identify as Forro, she did learn Forro during her undergraduate studies in Portugal. In the following excerpt, Sandra explains that contact with Cabo Verdeans (who use Cabo Verdean Creole in their everyday interactions) prompted her to learn and speak Forro. Her time in Portugal drove her to give more value to what is Santomean, and Forro for her developed into an important marker of her Santomean identity.

\section{Excerpt 3.}

E então, estar fora faz nos aprender a valorizar o que é nosso, quem somos realmente. Por exemplo, eu aprendi o crioulo forro lá fora. [Author: Ah é?] Estando lá fora, sim, comecei a dar maior importância ao crioulo lá fora. [...] Eu estudei muito com muitos caboverdianos e eles só falavam crioulo, entre eles, então os fins de semana quando ia pras comunidades onde estavam os Santomenses, eles estavam a falar crioulo. Eu acabei por me forçar muito mais para aprender, se bem que meu crioulo não é dos melhores não é. Mas já é alguma coisa. [Author: ok] Sim, eu comecei a dar maior importância porque... parece que isso identifica-me, faz-me Sandra Santomense. 'So, being abroad teaches us to value what is ours, who we really are. For example, I learned Forro abroad. [Author: Really?] When I was abroad, yes, I started to give greater importance to creole. [...] I studied a lot with many Cabo Verdeans and they only spoke their creole between each other, so during the weekend, when I'd go to the communities where Santomeans live, they spoke creole together. I ended up making an effort to learn it, although my creole is not the best one. But it's still something. [Author: ok] Yeah, I started to give greater importance to it because ... it seemed like it identifies myself, it makes me Sandra Santomean.'

(Sandra, 38 years old, interviewed in São Tomé City)

From this perspective, cultural and linguistic contact can be perceived as a driving force for the expansion and maintenance of Forro. The report of her experience suggests that Forro may be becoming an identity marker for all Santomeans, or at least for mixed-race and descendants of Cabo Verdeans such as Sandra, and not only of Santomeans who identify as Forros. Lüpke (2015) noted that individuals may claim membership in ethnic groups whose languages they do not speak natively or fluently. This might indicate, as Mufwene (2017: 205) wrote, that "language is often not the critical marker of ethnic/cultural identity." From this 
perspective, a language is not the only identifying marker of a group, and the symbolic relationship between a language and a group may change. As Santomean society is changing, so are the values and roles attributed to its language. Forro might have been associated, in the past, to Forros only, at a time where the different groups forming the population of São Tomé Island were mainly kept apart. But the massive arrival of contract laborers in the twentieth century and the greater contact between Forros and these populations have favored, I believe, the emergence of a Santomean identity that encompasses mixed-race individuals, such as Sandra. In this sense, Forro can be redefined as a language that belongs to all Santomeans.

Forro also acquired a new role among Santomeans outside São Tomé Island, the role of a secret code. This is explained by Clara in Excerpt 4. Note that the term dialeto 'dialect' is often used to refer to Forro. Although the term probably takes root in an ideology transmitted to Santomeans by Portuguese colonizers who perceived creoles as a corrupted version of Portuguese (Barbosa 1967), it is used nowadays without the negative connotation (Bouchard 2017).

Excerpt 4.

Eu acho que às vezes, quando quero falar com a minha mãe, às vezes falo com ela em dialeto porque nem todas as coisas que vou querer falar com ela eu quero que as pessoas saibam. Porque já que no meu quarto estão dez pessoas duma vez só, cama quase coloda uma com outra, então, eu não tenho muita privacidade.

'I think that sometimes, when I want to talk to my mother, sometimes I talk with her in Forro because I don't want people to know what I'm talking about. There are ten of us sharing a room, one bed beside another, so, I don't have a lot of privacy.'

(Clara, 21 years old, interviewed in Portugal)

In this case, Clara perceives and uses Forro as a sort of secret language, not to be understood by her non-Santomean roommates. Forro, Cabo Verdean Creole, and Guinean Creole are not mutually intelligible. Clara expresses in her interview that she feels close to her Santomean roommates, so she does not mind if they understand what she is sharing with her mother. The perceived need for a secret language is an outcome of contact with other Portuguese-speaking Africans (mainly Guineans and Cabo Verdeans in this case) who speak their national language, which most Santomeans and Portuguese nationals do not understand. The national language of each of these nationalities can be regarded as a we-code (Gumperz 1982) by the respective members of these groups (i.e., Cabo Verdean Creole is a "we-code" for Cabo Verdeans, and Guinea Creole is a "we-code" for Guineans). For Santomeans, Cabo Verdean and Guinean creoles are "they-code" because they do not speak it and they do not belong to these national groups. Mirroring these Portuguese-speaking Africans, the "we-code" for Santomeans would be Forro. The need for a "we-code" appears as a motivation for learning 
Forro. In Excerpt 4, Forro is said to be deliberately used by Clara to exclude outsiders in the ongoing conversation with her mother on the phone. Portuguese is the default choice when communicating together (with other people from Portuguese-speaking countries). For Guineans and Cabo Verdeans, who use their national language as a first language, and use it more frequently in their home country than Santomeans do, Portuguese might also be perceived as a "they-code" (Excerpt 5). But this is not necessarily the case for Santomeans.

As Gumperz (1982: 66) wrote, there is a tendency for the ethnically specific language to be perceived as the "we-code," and the majority language to serve as a "they-code." But on São Tomé Island, with the language shift from the creoles to Portuguese, the latter has become a "we-code" for Santomeans. It is the language of everyday interactions, and for many, their first and only language. But contact with other Portuguese-speaking Africans, who do have another language to express in-groupness and to create distance between their group and others, brings up a perceived need for an in-group code. Based on the experience of the Santomeans I interviewed, once they are abroad, in contact with other Portuguese- and creole-speaking Africans, a change in their attitudes toward Forro is initiated. As Forro becomes perceived as a "we-code," a language that can be used only by Santomeans among other Portuguese speakers, a language that can be used as a secret language, and a language that makes them feel Santomean, Forro gains value. In São Tomé, the lack of input in combination with negative attitudes results in a lack of motivation to acquire and use Forro. But the redefinition of Forro as an in-group language and identity marker when abroad (in Brazil and Portugal in the case of my participants) led to a redefinition of its value to a more positive one.

This change in the belief system and the more positive perception of Forro can also be observed among Santomeans who do not speak creole. In Excerpt 5, Flor shares her desire to speak Forro that has emerged from her everyday contact with Guineans in Portugal.

Excerpt 5.

Eu gostaria muito [de falar Forro]. Hoje quando vejo os guineenses a falar, tipo, dizia fogo, eu gostaria muito de aprender meu dialeto porque conversam entre eles também pa outras pessoas não perceberem, porque o... os guineenses falam muito crioulo [...] Uma parte isso é bom porque a cultura deles está a permanecer [Author: sim] e até outro dia ela me disse "Ah, eu não falo português porque não sou portuguesa, sou guineense portanto tenho que falar crioulo.” Depois eu disse, fogo! Sou santomense não sei falar dialeto.

'I'd really like to [speak Forro]. When I see Guineans speaking their creole, I'm like, gosh, I'd like to learn my creole, because they speak together in their creole so other people don't understand, because ... Guineans often speak creole. [...] That's partly good because their culture is maintained [Author: yes] and the other day, she 
told me “Ah, I don't speak Portuguese because I'm not Portuguese, I'm Guinean so I have to speak my creole.” Then I thought, gosh! I'm Santomean and I don't even speak Forro.'

(Flor, 20 years old, interviewed in Portugal)

Flor lives in a small community of Central Portugal that receives students from Portuguese-speaking Africa to ease the pressure of its aging population. She clearly expresses, through the narration of an interaction with a Guinean student, how her perception of Forro is challenged in contact with Guineans. First, as did Clara, she expresses her wish to speak Forro, in part to have an in-group code as Guineans do. Second, she highlights the relationship between Forro and Santomean identity by acknowledging what her Guinean colleague said. This link that is created between language and national identity certainly contributes to representing Forro as being part of what is authentically Santomean, and to strengthening her desire to learn Forro.

That being said, all the excerpts presented in this section indicate that the migratory experiences of Santomeans and their contact with other Portuguese- and creole-speaking Africans led to a redefinition of the roles and values associated with Forro, and that this redefinition seems to be favorable for the maintenance of Forro.

\section{Conclusion}

Migration for Santomeans entails a redefinition of their language resources. As the context changes with migration, the roles and values attributed to Forro change as well. Through the experience of Santomeans who have lived or still live abroad, I have demonstrated that the ideological positioning of Forro as having a low status in Santomean society is being challenged. For Santomeans who have experienced living in the diaspora, Forro gained a symbolic dimension, that of an identity marker. Speaking Forro makes Santomeans feel more Santomean. Forro becomes perceived as an asset that can help them feel a sense of belonging to a Santomean community that sets them apart from other Portuguese speakers and Africans. Thus, as a result of cultural and linguistic contact, Santomeans attach new perceptions to Forro. Forro also acquired a new role, that of an in-group code. Santomean participants expressed using Forro to communicate with Santomeans and to exclude non-Santomeans from the conversation. In other words, the symbolic value attached to Forro is one of authenticity and belonging. For Santomeans in the diaspora, Forro is an authentic expression of being Santomean. This feeling of belonging is linked to language use, and not necessarily to territoriality. The 
strengthening of the use of a creole language in diaspora communities has been observed as well among speakers of English-based creoles (e.g., Mair 2003 for Jamaican Creole).

That being said, no participants have explicitly mentioned any change in how they perceive Portuguese. Portuguese seems to remain commodified as the language associated with economic empowerment and social promotion. It remains the language of prestige and a necessary skill.

Among the criteria suggested by Lüpke and Storch (2013) and Lüpke (2015) for assessing the vitality of languages in African settings (Section 2), one could argue that Forro in the diaspora gains points on two criteria: (2) a home base for these communities of practice and social networks, and (4) community members' attitudes toward their own languages. First, the Santomeans communities in the diaspora, especially in Portugal where Santomeans are more numerous, serve as a community of practice, which contributes to expanding the possibilities of using Forro. While not all my participants used Forro when they were growing up on São Tomé Island, they did use it more frequently among their Santomean community abroad. Second, participants to this study have clearly expressed more positive attitudes toward Forro.

Interestingly, these findings also corroborate with my observations during field research; many Santomeans learn Forro at a later age - around 20 years old, in the case of the participants in this study. They probably had a passive knowledge of Forro before moving to Portugal, as many mentioned that they heard it in their surrounding when they were growing up, which probably facilitated their learning of the language once adult. One could expect Santomeans to learn Forro at home, with their parents or grandparents, and to then shift to Portuguese when they reach school age. This would be the case, for instance, in various societies where the heritage language or the vernacular is learned at home with family members, as in Haiti or Jamaica, for instance. This late acquisition of Forro among Santomeans most certainly has an impact on the language itself. Many Santomeans have mentioned the difference between the variety of Forro spoken by elders and the one spoken by adolescents and young adults. Because they acquire the language at a later age, it might sound like a second language variety, influenced by Santomean Portuguese. ${ }^{2}$ What the research participants perceive as Forro is certainly different from the variety of Forro spoken by elders on São Tomé Island, which they refer to crioulo aprofundado 'deep creole'. More studies on this topic would be of great interest.

Earlier in this paper, I asked: Can contact with Portuguese play a role in the maintenance of Forro? In this article, I argue that contact with Portuguese, as well

2 See Lipski (2012) for a similar discussion about “new” Palenquero in Colombia. 
as with other creole languages, plays a role in expanding the possibilities for using Forro. But while most Santomeans feel that it is important to maintain Forro, differences emerged with respect to what should be done. Like most contact languages, Forro and the other creoles of São Tomé and Príncipe lack political and economic power and support. But this study shows that Santomeans themselves have the power to transform attitudes, beliefs and practices. They are the real key actors for change, although their role might be underestimated, or even overlooked. This change could be pushed forward by Santomeans such as Alberto, Bibiana, Sandra, Clara and Flor, who came to, in contact with other creole speakers of Africa in Portugal and Brazil, associate Forro with other values than those they had attributed to it while growing up on São Tomé Island. In this sense, contact was a driving force for a redefinition of Forro and its role in the Santomean community.

\section{References}

Agostinho, Ana L. 2014. Fonologia e método pedagógico do lung'ie. São Paulo: Universidade de São Paulo Dissertation.

Agostinho, Ana. 2016. Fonologia do lung'ie. München: Lincom.

Agostinho, Ana, Manuele Bandeira \& Gabriel A. de Araujo. 2016. 0 Lung'le na educação escolar de São Tomé, São Tomé e Príncipe. Trabalhos em Lingüística Aplicada 55(3). https://doi.org/10. $1590 / 010318135164183401$.

Appadurai, Arjun. 1986. Commodities and the politics of value. In Arjun Appadurai (ed.), The social life of things: Commodities in cultural perspective, 3-63. Cambridge: Cambridge University Press.

Araújo, Gabriel, AnaAgostinho, VanessaAraújo \& ManueleBandeira. Dicionário Lung'le-Português (in preparation).

Araújo, Gabriel \& Tjerk Hagemeijer. 2013. Dicionário Livre Santome-Português. São Paulo: Hedra Educação.

Araújo, Vanessa Pinheiro de. 2012. Um dicionário Principense-Português. São Paulo: Universidade de São Paulo MA thesis.

Austin, Peter \& Julia Sallabank. 2014. Endangered languages: Beliefs and ideologies in language documentation and revitalization. Oxford: Oxford University Press.

Barbosa, Jorge M. (ed.). 1967. Estudos linguísticos crioulos. Lisbon: AICP.

Batibo, Herman. 2009. The inter-cultural dimension in the use of languages of wider communication by minority language speakers. Journal of Multicultural Discourses 4(2). 89-102.

Belew, Anna \& Sean Simpson. 2018. The status of the world's endangered languages. In Kenneth Rehg \& Lyle Campbell (eds.), The Oxford handbook of endangered languages. London/New York: Routledge.

Bouchard Marie-Eve. Forthcoming a. The use of Angolar: A study of attitudes on São Tomé Island. Bouchard Marie-Eve. Forthcoming b. Singing in creole of Portuguese? The symbolic meaning of languages in Santomean musical manifestations. 
Bouchard, Marie-Eve. 2017. Linguistic variation and change in the Portuguese of São Tomé. New York: New York University Dissertation.

Bouchard, Marie-Eve. 2019a. Language shift from Forro to Portuguese: Language ideologies and the symbolic power of Portuguese on São Tomé Island. Lingua. https://doi.org/10.1016/j. lingua.2019.06.013.

Bouchard, Marie-Eve. 2019b. Becoming monolingual: The impact of language ideologies on the loss of multilingualism on São Tomé Island. Languages 4(50). https://doi.org/10.3390/ languages 4030050.

Bourdieu, Pierre. 1991. Langage et pouvoir symbolique [language and symbolic power]. In John B. Thompson (ed.), trans. by Gino Raymond and Matthew Adamson. Cambridge: Harvard University Press.

Del Percio, Alfonso, Mi-Cha Flubacher \& Alexandre Duchêne. 2017. Language and political economy. In Ofelia Garcia, Nelson Flores \& Massimiliano Spotti (eds.), The Oxford handbook of language and society, 55-76. Oxford: Oxford University Press.

Dijkhoff, Marta \& Joyce Pereira. 2010. Language and education in Aruba, Bonaire and Curaçao. In Bettina Migge, Isabelle Léglise \& Angela Bartens (eds.), Creoles in education: An appraisal of current programs and projects, 237-272. Amsterdam: John Benjamins.

Eberhard, David, Gary Simons \& Charles Fennig. 2020. Ethnologue: Languages of the world, 23rd edn. Dallas, Texas: SIL International. https://www.ethnologue.com/ (accessed 6 May 2020).

Fishman, Joshua. 1991. Reversing language shift: Theory and practice of assistance to threatened languages. Clevedon: Multilingual Matters.

Gal, Susan. 1989. Language and political economy. Annual Review of Anthropology 18. 345-367.

Garrett, Paul. 2006. Contact languages as "endangered" languages: What is there to lose. Journal of Pidgin and Creole Languages 21(1). 175-190.

Garrett, Paul. 2012. Dying young: Pidgins, creoles and other contact languages as endangered languages. In Genese Marie Sodikoff (ed.), The anthropology of extinction: Essays on culture and species death, 143-162. Bloomington: Indiana University Press.

Gonçalves, Rita \& Tjerk Hagemeijer. 2015. 0 português num contexto multilingue: 0 caso de São Tomé e Príncipe. Revista Científica da Universidade Eduardo Mondlane 1(1). 87-107.

Gumperz, John. 1982. Discourse strategies. Cambridge: Cambridge University Press.

Hagemeijer, Tjerk. 2009. As línguas de São Tomé e Príncipe. Revista de Crioulos de Base Lexical Portuguesa e Espanhola 1(1). 1-27.

Hagemeijer, Tjerk. 2018. From creoles to Portuguese: Language shift in São Tomé and Príncipe. In Laura Alvarez López, Perpétua Gonçalves \& Juanito Ornelas de Avelar (eds.), The Portuguese language continuum in Africa and Brazil, 169-184. Amsterdam: John Benjamins.

Harrison, David. 2007. When languages die: The extinction of the world's languages and the erosion of human knowledge. Oxford: Oxford University Press.

Hebblethwaite, Benjamin. 2012. French and underdevelopment, Haitian Creole and development. Journal of Pidgin and Creole Languages. 27(2). 255-302.

Heller, Monica. 2003. Globalization, the new economy, and the commodification of language and identity. Journal of SocioLinguistics 7(4). 473-492.

Heller, Monica. 2010. The commodification of language. Annual Review of Anthropology 39. 101-114.

Instituto Nacional de Estatística (INE). 2012. Resultados nacionais. IV Resenceamento geral da população e da habitação. http://www.ine.st/Documentacao/Recenseamentos/2012/ DDENRAP/Resultados\%20Nacionais\%20do\%20IV\%20RGPH\%202012\%20novo.pdf (accessed February 12, 2020). 
Irvine, Judith. 1989. When talk isn't cheap: Language and political economy. American Ethnologist 16(2). 248-267.

Kouwenberg, Silvia \& John Singler (eds.). 2008. The handbook of Pidgin and Creole studies. Oxford: Wiley-Blackwell.

Lavres, Nicolau \& Maria Lavres. 2016. Vika xina lung'ie - Vem aprender lung'ie. São Tomé and Príncipe.

Lee, Nala. 2017. The vitality or endangerment of some nonindigenous languages: A response to Mufwene. Language 93(4). e234-e242.

Lee, Nala. 2018. Contact languages around the world and their levels of endangerment. Language Documentation \& Conservation 12. 53-79.

Lee, Nala. 2020. The status of endangered contact languages of the world. Annual Review of Linguistics, 6. 301-318.

Lee, Nala \& John Van Way. 2016. Assessing levels of endangerment in the catalogue of endangered languages (ELCat) using the language endangerment index (LEI). Language in Society 45(2). 271-292.

Lewis, Paul \& Gary Simons. 2010. Assessing endangerment: Expanding Fishman's GIDS. Revue Roumaine de Linguistique 55(2). 103-120.

Lipski, John. 2012. Thenew Palenquero: Revitalization and re-creolization. In Richard File-Muriel \& Rafael Orozco (eds.), Colombian varieties of Spanish, 21-42. Madrid: Iberoamericana.

Lorenzino, Gerardo. 1998. The Angolar Creole Portuguese of São Tomé: Its grammar and sociolinguistic history. New York: City University of New York dissertation.

Lüpke, Friederike. 2015. Ideologies and typologies of language endangerment in Africa. In James Essegbey, Brent Henderson \& Fiona McLaughlin (eds.), Language documentation and endangerment in Africa, 59-16. Amsterdam: John Benjamins.

Lüpke, Friederike, and Anne Storch. 2013. Repertoires and choices in African languages. Berlin: De Gruyter.

Mair, Christian. 2003. Language, code, and symbol: The changing roles of Jamaican Creole in diaspora communities. Arbeiten aus Anglistik und Amerikanistik 28. 231-248.

Makihara, Miki \& Bambi Schieffelin (eds.). 2007. Consequences of contact: Language ideologies and sociocultural transformations in Pacific societies. Oxford: Oxford University Press.

Maurer, Philippe. 1995. L'angolar: Un créole afro-portugais parlé à São Tomé. Helmut Buske Verlag, Hamburg.

Maurer, Philippe. 2009. Principense (Lung'le): Grammar, Texts, and Vocabulary of the AfroPortuguese Creole of the Island of Príncipe, Gulf of Guinea. Battlebridge, London.

Mazrui, Ali \& Alamin Mazrui. 1998. The power of Babel: Language and Governance in the African experience. Oxford: James Currey; Nairobi: E.A.E.P.; Kampala: Fountain Publishers; Cape Town: David Philip Publishers; Chicago: University of Chicago Press.

Milroy, Lesley. 1980. Language and social networks. New York: Blackwell.

Mufwene, Salikoko. 2017. Language vitality: The weak theoretical underpinnings of what can be an exciting research area. Language 93(4). e202-e223.

Mufwene, Salikoko \& Cécile Vigouroux. 2008. Colonization, globalization and language vitality. In Cécile Vigouroux \& Salikoko Mufwene (eds.), Globalization and language vitality: Perspectives from Black Africa, 1-31. London: Continuum Press.

O’Shannessy, Carmen. 2012. Language contact and change in endangered languages. In Peter Austin \& Julia Sallabank (eds.), The Cambridge handbook of endangered languages, 78-99. Cambridge: Cambridge University Press. 
Perez, Danae. 2019. Language competition and shift in New Australia, Paraguay. London: Palgrave Macmillan.

Pontífice, João, Alcântara Caustrino, Beatriz de Castro Afonso, Tjerk Hagemeijer \& Philippe Maurer. 2010. Alfabeto Unificado para a Escrita das Línguas Nativas de S. Tomé e Príncipe (ALUSTP). Unpublished.

Sallabank, Julia. 2013. Attitudes towards endangered languages: Identities and policies. Cambridge: Cambridge University Press.

Sankoff, Gillian. 2001. Linguistic outcomes of language contact. In Peter Trudgill, Jack Chambers \& Natalie Shilling-Estes (eds.), Handbook of sociolinguistics. Oxford: Basil Blackwell.

Seibert, Gerhard. 2006. Comrades, clients and cousins: Colonialism, socialism and democratization in São Tomé and Príncipe. Leiden: Brill.

Siegel, Jeff. 2008. The emergence of Pidgin and Creole languages. Oxford: Oxford University Press.

Swadesh, Morris. 1948. Sociological notes on obsolescent languages. International Journal of American Linguistics 14. 226-235.

Thomason, Sarah. 2018. Language contact and language endangerment. In Kenneth Rehg \& Lyle Campbell (eds.), The Oxford handbook of endangered languages, 66-81. Oxford: Oxford University Press.

UNESCO. 2003. Language vitality and endangerment. International Expert Meeting on UNESCO Programme Safeguarding of Endangered Languages. http://www.unesco.org/new/ fileadmin/MULTIMEDIA/HQ/CLT/pdf/Language_vitality_and_endangerment_EN.pdf (accessed 8 May 2020).

Valkhoff, Marius. 1966. Studies in Portuguese and Creole: With special reference to South Africa. Johannesburg: Witwatersrand University Press.

Wassink, Alicia Beckford. 1999. Low prestige and seeds of change: Attitudes toward Jamaican Creole. Language in Society 28(1). 57-92. 